JOURNAL OF BORNEO-KALIMANTAN(JBK)

\title{
The Tuai Rumah in Brunei Darussalam: Continuity and Challenges
}

\author{
Li Li Pang* \\ UBD School of Business and Economics, Universiti Brunei Darussalam \\ *Corresponding author \\ lili.pang@ubd.edu.bn
}

\begin{abstract}
Research on the Iban community in Brunei Darussalam, whose lifestyles and leadership structure are recognized by the government, is scarce. This paper is an attempt to understand the role of the Tuai Rumah, the leader of an Iban longhouse and a recognized administrative position in the country's local administration as well as the challenges they face in 'administrating' in their community. The community's culture and tradition are endangered as younger members of the community have moved to urban areas in search of employment and better access to public services and are not exposed to their ancestors' traditional lifestyles. It is possible that the institution of the Tuai Rumah may be abolished in the next decade unless the government re-consider strategies to improve and invest in rural development.
\end{abstract}

Keywords: Ibans, Tuai Rumah, Ketua Kampong, Penghulu, Leadership, Brunei

\section{INTRODUCTION}

Negara Brunei Darussalam, (henceforth, Brunei) is a Malay Muslim Monarchy. In 1962, the government passed the Nationality Act which recognizes the seven indigenous ethnic groups namely, Brunei Malay, Tutong, Belait, Dusun, Murut, Kedayan and Bisaya as Malays and they automatically become citizens of the state. The Iban or Sea Dayaks are recognized as 'other indigenous' citizens of the country and are considered to be ethnically and culturally different from the Malays. The Ibans of Brunei prefer to be known as Iban rather than Dayaks or Sea Dayaks and the term is also commonly used by the government and in the national media. The government recognizes the community's leadership and the Tuai Rumah (henceforth Tuai, plural Tuais), the leader of an Iban longhouse, have become salaried public servants since 2004. Research on the Ibans, or any other ethnic indigenous in Brunei is scarce, so too is the research on the local governance in Brunei in general and as part of the research on local governance at village and sub-district level (Pang, 2018), this paper looks at the position of the Tuai, a previously unresearched topic, on their challenges and continuity in Brunei.

\section{THE IBANS OF BRUNEI DARUSSALAM}

Historically, the Iban are famous for their headhunting and territorial expansion skills (Coluzzi, 2010). They could be called on by the Sultan of Brunei to serve as a 'volunteer army usually ready and willing to attack recalcitrant subjects' (Brown, 1970:4). They are said to be originally from Kalimantan and as the tribe traveled across Borneo, they came to the borders of present-day Brunei around the 1900s (Brown, 1970; Sercombe, 1999; de Vienne, 2015). Most of them settled in southern Belait, Tutong and Temburong districts (see Figure 1).

Coluzzi (2010) estimated that there are about 20,000 Ibans living in Brunei, while Minority Rights Group International (MRGI, 2018) estimated that Ibans account about 4.7\% of Brunei's total population which brings it to about 19,800 people. However, these numbers should be treated with 
caution as Brunei statistical yearbooks have recorded lower numbers, less than 14,000 people classified as 'other indigenous' in the country's national data (See Table 1).

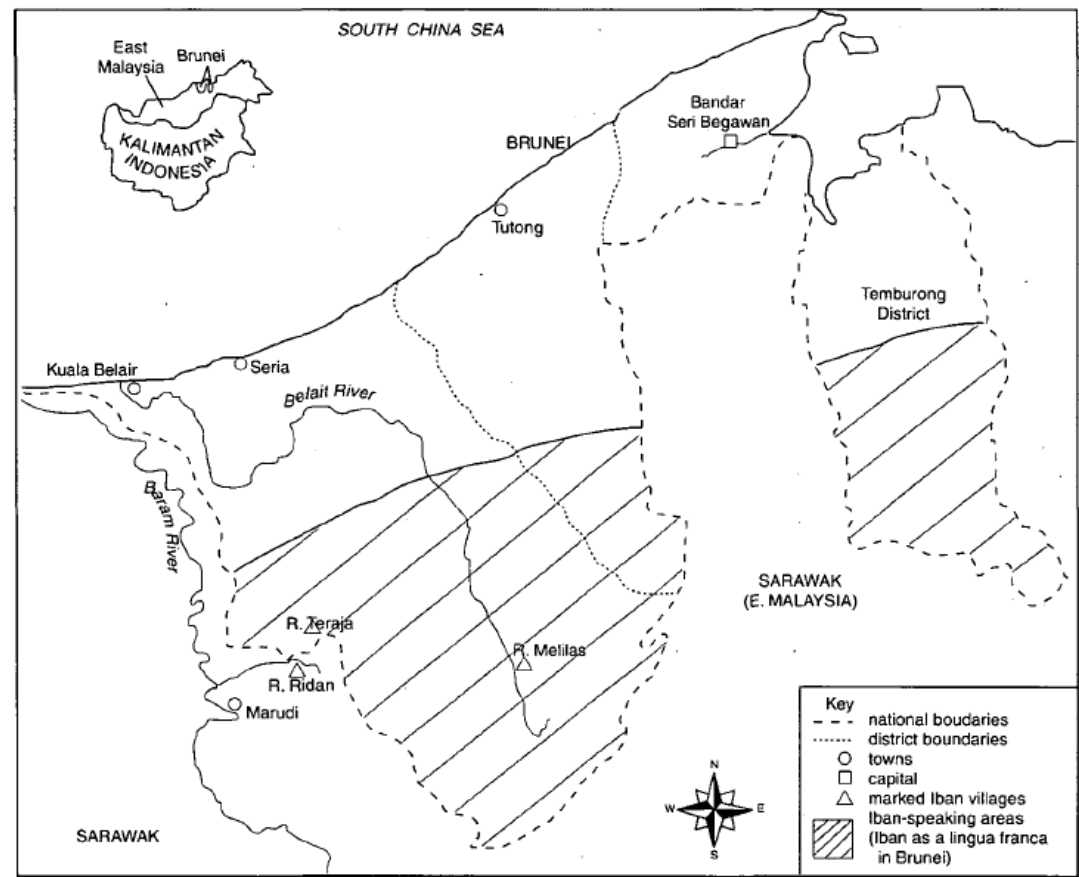

Figure 1. The Traditional Settlement of Iban Communities in Brunei Darussalam (Source:

Sercombe, 1999).

The national population census report does not identify the individual ethnic group in its listing despite the Nationality Act listing 15 ethnic groups under its 'other indigenous' category (Land and Sea Dayaks are categorized differently, see Appendix 1). Based on the 2011 population census, the majority of the 'other indigenous' population lived in Belait $(4,750)$, followed by Brunei-Muara $(4,460)$, Temburong $(2,173)$ and Tutong $(1,897)$ Districts respectively (Jabatan Perancangan dan Kemajuan Ekonomi (JPKE), 2018). The data from JPKE shows that a majority of the 'other indigenous' population worked with the government and based on the data on Table 1, it is clear that there is a sharp increase by 77\% from 1971 to 1981 and a sharp decline between 1991 and 2001 of 'other indigenous' population in the census. A short discussion on this discrepancy will be presented in the later part of this paper.

Table 1

Population by Race, Annual Rate of Increase and Year of Census

\begin{tabular}{lccccc}
\hline Race & 1971 & 1981 & 1991 & 2001 & 2011 \\
\hline Other Indigenous & 8,552 & 15,175 & 15,665 & 11,699 & 13,280 \\
\% Increase & - & 77.4 & 3.2 & -25.3 & 13.5 \\
\hline
\end{tabular}

Note. Adapted from JPKE (2018)

\section{Local Administration}

Historically, in the $16^{\text {th }}$ century, Brunei had a large empire, stretching across present-day Sarawak, Sabah and the Philippines with many different tribes pledging allegiance to the Brunei Sultanate. The Brunei Sultanate allowed the local indigenous population to maintain their traditional cultures and lifestyles and this continued when Britain became Brunei's protector in 1888. The 1910 Report on Brunei noted "The government upholds local 'adat' or customs... in all religious matters, eg as affecting marriage, divorce and ceremonial" (Chevallier, 1910:17). As an example, the Chinese who 


\section{Li Li Pang}

became a significant minority after the end of the Second World War, witnessed the government adopting the Chinese Marriage Enactment 1955 (now Chapter 126 of Chinese Marriage Act) which governs the Chinese marriage according to their law and customs. To this day, the Chinese registrars of marriage are still appointed by the Sultan of Brunei.

In this paper, the role of the Tuai of the Iban community is highlighted. Several prior research on the community had focused on the community's language vitality and assimilation with the broader Malay language (Morrison, 1995; Sercombe, 1999; Coluzzi, 2010). As part of the paper presented on the institutions of Penghulu and Ketua Kampongs (KK), the community leaders of a sub-district (Mukim) and a village respectively, in Brunei (Pang, 2018), the data given by the District Office included 'Ketua Ramah Panjang' (Table 2), therefore this paper provides an extension to the research on the local governance in Brunei by focusing on the Tuai. Tuai is the only minority community leader whose leadership in the sub-village area is recognized by the government. Although Chinese community leaders have been appointed as life peers in Brunei's royal court, for example, Pehin Kapitan Cina, (Pang, 2015), however, it is different as most of the Chinese appointed are business entrepreneurs and arguably not community leaders at the 'lower' society level where the community can easily seek help. The fact that the government recognizes and provides salaries to Tuai shows the government's continued support to the community, recognizing their distinct culture, identity and leadership structure.

Table 2

Number of Penghulu, Ketua Kampongs and Long House Chiefs (Tuai Rumah), January 2018

\begin{tabular}{lcccccc}
\hline \multirow{2}{*}{ Districts } & \multicolumn{2}{c}{ Penghulu } & \multicolumn{2}{c}{ Village Head } & \multicolumn{2}{c}{$\begin{array}{c}\text { Long House Chief } \\
\text { (Ketua Rumah Panjang) }\end{array}$} \\
\cline { 2 - 7 } & Position & Filled & Positions & Filled & Positions & Filled \\
\hline Brunei Muara & 18 & 13 & 116 & 80 & Nil & Nil \\
Belait & 8 & 3 & 19 & 10 & 9 & 5 \\
Tutong & 8 & 7 & 32 & 24 & 1 & 0 \\
Temburong & 5 & 5 & 18 & 13 & Nil & Nil \\
Total & 39 & 28 & 185 & 127 & 10 & 5 \\
\hline
\end{tabular}

Note. Source: Pang (2018)

As of January 2018, there are five recognized Tuais in Brunei and all of them are located in the rural Belait District (Table 3). Although the government provides for nine Tuais in the Belait District, only five have been confirmed. Four other Tuais were not appointed either because the previous Tuais have retired, passed away, the positions are awaiting confirmation from the Ministry approval or since there are fewer residents, there is no need to appoint a Tuai. For example, although there is provision for a Tuai in Tutong District, however, based on an interview with an officer from District Office, the position will be abolished as there are fewer people living in the longhouse and the responsibility of the people in the longhouse will be transferred to the KK of the area.

Table 3

Five Recognized Tuai Rumah in Brunei, January 2018

\begin{tabular}{lc}
\hline \multicolumn{1}{c}{ Long House } & $\begin{array}{c}\text { Estimated Distance from Lumut Town, } \\
\text { Belait District }\end{array}$ \\
\hline Malayan, Mukim Bukit Sawat & $25 \mathrm{~km}$ \\
Mendaram Besar, Mukim Labi & $52 \mathrm{~km}$ \\
Biadong Ulu, Mukim Sukang & $68 \mathrm{~km}$ \\
Buau, Mukim Sukang & $61 \mathrm{~km}$ \\
Melilas, Mukim Melilas & $70 \mathrm{~km}$ \\
\hline
\end{tabular}


The furthest location of a longhouse with a salaried Tuai is in Melilas, Belait District. To reach Melilas from Lumut town takes about three to four hours depending on road condition. The only road towards Mendaram Besar, which is near to Teraja is paved with bitumen, providing easy access to interior Brunei.

In terms of administrative structure, the Ministry of Home Affairs (MOHA) though the District Office oversees the institution of the community leaders at sub-district, village and longhouses (Figure 2). In villages which have Tuais, the Tuais will report to KK on issues which may need their attention affecting the longhouse residents and surrounding its areas and if there are no Tuais being appointed, the KK will look after the areas which included the longhouse area.

KK then reports to Penghulu and Penghulu as leader of the sub-district or Mukim, will then report to the District Office for matters which needs District Office or the Ministry's attention. Despite having an administrative structure as explained above, all officials have direct access to the District Office. Penghulu, KKs and Tuais have regular meetings at the District Office located in Kuala Belait, the administrative capital of Belait District. There is no strict hierarchy or rigidity imposed though, in terms of official paperwork, certain procedures may have to be followed.

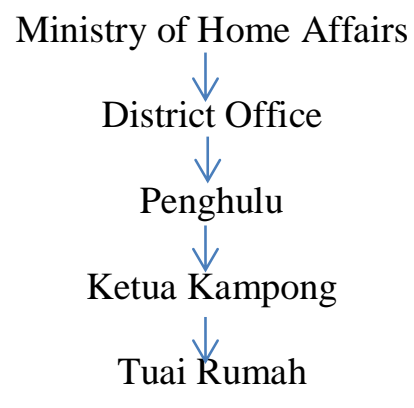

\section{Figure 2. Administrative Structure of the District Office}

To this author's knowledge, no research has been made on the relationship between the Tuai and the local governance system in Brunei, therefore, this research aims to fill that literature gap. As ruralurban migration is a global phenomenon, it is pertinent to look at the roles of the Tuais who faced dwindling number of residents due to that reason and understand the challenges they face as a Tuai.

\section{METHODOLOGY}

Since there are only five recognized Tuais in Brunei in 2018, qualitative research method involving face to face interviews were adopted for this research. Semi-structured interviews allow more in-depth probing (Halperin and Heath, 2017) where richer primary information can be obtained. A list of questions was prepared and the Tuais were interviewed in their homes, except two. One of the interviews was held at the Tuai's residence in Lumut as he was ill therefore being in town made it easier for him to go to the hospital while the second interview was held at a restaurant in Tutong town as the Tuai went to the town to conduct some personal errands.

The interviews with four of the Tuais took place in July 2018 and the final interview took place in August 2018. The interviews lasted between one to two hours. The researcher was helped by her former student, and her aunt, who spoke the Iban language when the questions in Malay or English were not easily understood by the Tuais. It helped that Tuais knew the student and her aunt; hence they were comfortable in answering the questions. It was revealed in the interviews that the Iban community is a close-knit society due to the fact that most of them are interrelated; the student and her aunt are part of their extended family network. According to the Tuais, a majority if not all of the ancestors of the Ibans in the Belait and Tutong Districts migrated from the bordering Marudi town of 


\section{Li Li Pang}

Baram District, Sarawak. Baram District in Sarawak used to be part of Brunei before it was annexed by the Rajah of Sarawak in 1883.

For reasons of confidentiality and anonymity, the names of the Tuais during the interviews will not be identified directly in this paper. Their characteristics are listed in Table 4 and since it would be easy to find out who they are as there are only five of them, this paper will not identify the specific Tuai who is quoted in this paper. It is the moral and ethical responsibility of the researcher to ensure that their respondents are protected, so that they are not harmed or exploited, directly or indirectly because of a research (Halperin \& Heath, 2017).

Table 4

Characteristics of Interviewed Tuai Rumah

\begin{tabular}{ccccc}
\hline Tuai & Age & Duration in Position & $\begin{array}{c}\text { Establishment of } \\
\text { Longhouse }\end{array}$ & $\begin{array}{c}\text { No. of People He } \\
\text { Looks After }\end{array}$ \\
\hline A & 67 & 17 & 1948 & 53 \\
B & 43 & 43 & $1940 \mathrm{~s}$ & 50 \\
C & 27 & 24 & 1949 & 50 \\
D & 13 & 13 & $1940 \mathrm{~s}$ & 52 \\
E & 20 & 20 & $1940 \mathrm{~s}$ & 35 \\
\hline
\end{tabular}

While the findings from the Tuais are important, to confirm the answers, an informal meeting with an official of the MOHA was also held to get a clearer timeline on the administrative roles and responsibilities of the Tuais in Brunei.

\section{FINDINGS}

\section{Similarities and Differences with Ketua Kampongs}

Penghulus, KK and Tuais, are part of the country's local governance and administration, looking after the people at the sub-district (Mukim), village and sub-village level respectively. They are representatives of the government and are considered as 'public servant' under the penal code (Ministry of Home Affairs (MOHA), 1992a,b). While Penghulu and KK were given a salary and allowances much earlier, the Tuais were only given a salary since 1st April 2004. Previously, under the 1992 Skim Perkhidmatan Ketua Rumah Panjang (Scheme of Service for the Ketua Rumah Panjang), (MOHA, 1992b) Tuais were only given allowance of $\mathrm{B} \$ 400$ per month for their position. Tuais' salary is lower compared to Penghulu and KKs, being similar to public servants in Division V as the salary reflects the small number of people he looks after when compared to a village or a Mukim (sub-district). All Penghulus, KKs and Tuais are given a signboard outside their house indicating their position; they are all invited to national events and important royal events in the Palace.

Tuais are representatives of the people living in the longhouses. They are the ones who provide supporting documents and official stamps if their residents seek government approval for any assistance just like Penghulus and KKs. The Tuais work closely with the Penghulu, KKs and District Office and they are in group communication, using media such as What's App where information can be shared fast and cheaply and quicker action can be taken by respective government agencies when needed.

For a longhouse to have a Tuai, there must be more than 7 doors in the longhouse, or more than 50 people living in the longhouse (MOHA, 1992b). While Penghulu and KK must be citizens of the country, for the positions of the Tuai, a Permanent Residents (PR) can be appointed as Tuai. Those eligible to be a Tuai must be above 30 years old and not more than 65 years old (MOHA, 1992b). This is different from the Penghulu and KK initially, based on the 2015 Scheme of Service, they have to be above 45 years of age before they can be eligible (MOHA, 2015). However, this was also changed recently when the Minister of Home Affairs suddenly announced that the age of Penghulu 
and KK is now lowered to 30 years of age (Azahari, 2018). As the Permanent Secretary of the Ministry noted,

"We want leaders with new ideas, and with the current state of the country, we need more leaders with a more dynamic ways of thinking, those who can make use of technology to better their community's socioeconomic standing" (Wasil, 2018).

Positions of Tuais have been abolished before. For example, previously there were about seven Tuais in Temburong District, however, with fewer number of people living in the longhouse, other Tuais have been 'promoted' to $\mathrm{KK}$ as they look after residents in the whole village, not just of the longhouse. Now there are four Ibans who are recognized as KK instead of Tuai in their area, namely the KK of Sibut, Amo, Lepong Baru and Tanjung Bungar (Temburong District Office Website, 2018). By virtue of their rank as KK, when they look after more residents, they would have a higher salary compared to a Tuai. As of 2018, there are no more officially recognized Tuai in Temburong District.

\section{Tuai Rumah's Appointment}

Traditionally, the Tuai is appointed by people living in the longhouse and it is usually patrilineal, an inherited position, from father to son. With the advent of modern administration and governance, in Brunei, the Tuai has to have the support from the residents of his longhouse before his name is forwarded to the KK and Penghulu who then informs the District Office. Of the five interviewed, there were two Tuais who said their recommendations come from the District Office directly. For example, Tuai $Z$ was asked by the District Officer (DO) to become the Tuai, the first salaried Tuai of the house as previously there was no Tuai in the area. The DO recommended the Tuai because the KK of the area has spoken highly of him; therefore, the DO heeded the advice of the KK, recommended Tuai $\mathrm{Z}$ to become Tuai of the longhouse. In the case of Tuai $\mathrm{Y}$, he claimed that he was also recommended by the District Office as he has worked in the Office before, and with the approval of the people of the longhouse, he was selected as Tuai. There is a provision in the 1992 Scheme of Service (MOHA, 1992b) where the DO can suggest the establishment of the position to the government should he see the need for it in the community.

While the appointments seemed straightforward, however, there is one Tuai who had a different experience. Tuai $\mathrm{X}$, who was the son of the previous Tuai took over from his father but he was not formally recognized by the government and was not given any salary. As he was formally recognized by the people of the longhouse, he had to do social and administrative tasks as expected of a Tuai. He 'resigned' from his position as he did not want the responsibilities without pay and it was only over a year later that the government formally recognized him and gave him a salary and allowance for him to undertake his tasks.

From the data gathered of the five Tuais in Table 4, it is clear that the Tuais in the Belait district are in position for a significant period of time, the longest, at 43 years and the shortest at 13 years. Tuai B had over 43 years of leadership experience and was appointed at the age of 27 years old after the death of his father who was the previous Tuai. As the Scheme of Service was only published in 1992, being younger than 30 years old at that time was not an issue for him to be appointed and recognised by his longhouse residents. Since the people in the longhouse had recognised him as the Tuai, so did the government.

\section{Not Responsible to Collect Elderly Pension}

Tuai is not mandated to collect old age pension and distribute it to people in his longhouse. He can collect it on behalf of the people living in his longhouse either from the KK or Penghulu. This lessens the burden of the Tuai to collect the money at the Ministry of Culture, Youth and Sports branch in Kuala Belait. As Tuai X noted, "If I'm to collect the pension, it will be about B $\$ 3,000$ per month. I worry about that large amount of money, so it is better that I leave it to the Ketua Kampong to do it." The challenge of collecting welfare assistance to give to the residents in the villages was also highlighted by KK (Pang, 2018). 


\section{Head of Religion and Culture}

The Tuais are said to be the head of their religion and culture of their respective longhouses. Most Iban are traditionally animists with many others converting to Christianity or Islam. The Tuais said that as long as they are family members of the specific longhouses, even though they work and live in urban areas, family members usually still go back to the longhouse to seek informal permission and advice from the Tuais on the suitability of their partners. The Tuais also have to write letters of approval if the partners are a non-Bruneian citizen and he also has to attend the civil wedding ceremony in the court as a witness. The Tuais are the point of reference in the proper handling of traditional weddings and in times of death. They are responsible to make sure proper death rituals are followed and where the body can be placed in the longhouse for the ceremony. For residents who have embraced Islam, the Tuais will not interfere in their marriage or death as it would be religiously inappropriate. Of the five longhouses, Sukang has the highest number of residents who are Muslims, where $90 \%$ of their residents have embraced Islam. The Tuai is not only a Muslim but was also given a peerage title by the Sultan of Brunei.

The Tuais are also 'judge' in the longhouse as they decide on punishment in event of residents' disputes and the fines should be imposed on the residents. Normally things are settled in the longhouse. No serious crimes have been reported although one Tuai mentioned thefts had occurred in his longhouse and requested the police to build a police post. Another Tuai also requested a police post as it borders neighboring Sarawak and cross-border incidents have happened in the past hence added security would be good for the people living in the area. It is the Tuai's task to report to the authorities on incidents of foreign nationals' encroachment into the state territory (MOHA, 1992a).

\section{Challenges Faced by Tuai Rumah Communication}

The furthest roads into interior Belait District are those towards Teraja and Melilas which is over $50 \mathrm{~km}$ away from the main Seria/Tutong highway. While the road to Teraja is paved with bitumen, the road to Melilas is not and still under construction. Residents who wish to go back to Melilas have to endure over three or four hours of journey by car as the road is filled with potholes and if it rains, the road becomes muddy. Logging activities with big trucks transporting huge logs are the main culprit of the road destruction. It is mainly due to this reason that there are fewer number of residents who are willing to go back from their urban workplace to the longhouse in rural Belait as the journey is too long, arduous and tedious to undertake.

As there are fewer people who live in the rural area mobile signals are non-existent. Three Tuais said they can receive Malaysian mobile signals as they are located closer to the Sarawak border. One of the Tuais believes that the mobile phone towers will be erected soon and by 2019, their longhouse will be able to receive the mobile connection and while waiting, he had to place his mobile phone outside his house to get signals in case there are messages sent to his mobile phone. Although a telephone line to the longhouse is installed however it is often not stable, especially after the rain. One Tuai said that his landline was down for the past three years and despite repeated requests to have it fixed it, it has not. As there is neither mobile communication nor a stable landline connection, younger residents who are used to such facilities in the urban areas face difficulties in adapting living in rural forested areas if they go back to the longhouse.

\section{Access to Electricity}

Longhouses around Sukang use generators for electricity as there are no electric poles to the area. The District Office has recently (in May 2018) erected solar-powered lamp posts near the longhouses and at night, the solar power lamps shine brightly. Solar energy panels were also used in the longhouses; however, it is not enough to power the longhouse. The Tuais were assured by the District Office that more solar power panels will be given in the near future. 


\section{Li Li Pang}

All Tuais argued that their longhouses will be full of people during weekends as that is the time that the residents will come back from work and visit their families, however, during the weekdays (when the interviews were carried out), it can be seen in three of the longhouses, that less than 10 elderly residents were in the longhouses.

\section{Continuing Lifestyle Challenges}

Based on the interviews with the Tuais in Belait, it was reported that the traditional longhouses built in rural Belait were actually built by the Ibans from Sarawak, notably Marudi, as the Brunei Ibans do not have the manpower nor the skills to build their longhouses. The Brunei Ibans engaged their friends from the border to cross the border to build their houses. Back then, border security was not so strict, therefore, the people could move easily in and out of the border. The Brunei Ibans paid the Sarawak Ibans and provided the raw materials from them to build their houses.

As more residents moved to the urban areas, it became harder to maintain the number of people living in the area. This not only occurs in Brunei but also in neighboring Sarawak (The Borneo Post, 2013, October 15th; The Borneo Post, 2016, July 3rd). It is not economically viable for the government to set up schools for less than five students, therefore the children have to be sent to the towns for their education. As their parents are also working in towns, it is easier for them to stay there than in a rural area. Brunei introduced Compulsory Education Act 2007 therefore parents who do not send their children to schools can be reported to the Ministry.

In terms of leadership succession of the next Tuai, one of the Tuais has indicated that his children are not interested to take over the job, therefore, he has to train his relatives for the job. The difficulties in finding the next successor in the community are also happening in urban areas (Pang, 2018), and the government is now trying to find replacements for a majority of all village and Mukim leaders (Wasli, 2018). With fewer people living in the area, it is highly possible that the government will abolish the Tuai position and KKs can be mandated to look after the longhouse.

While Coluzzi (2010) reported that most Ibans still lived in longhouses, however, this research found that many are living in urban areas and presumably come back during the weekend to their longhouse, as reported by the Tuais in this research. The Ibans in Brunei cannot be generally assumed to be living in the longhouse anymore.

\section{DISCUSSION}

Although the country's national philosophy is Malay Muslim Monarchy or its Malay acronym, MIB, the rights of the minorities are still protected by the Constitution and given recognition (Pang, 2015). As discussed, the Iban lifestyles are protected by the government, exemplified by the recognition of the Tuais position by the government as well as the establishment of a Community Heritage House in Tutong District. Ibans who are citizens of Brunei enjoy similar benefits such as subsidized free education, healthcare, old age pension and access to public housing and employment in the public sector (except the armed forces). Residents who contributed significantly to the country are also honoured with peerage and titles, regardless of their race and gender.

A few prominent Ibans who has been given titles in the Brunei royal court need to be highlighted to recognize their contribution to the country. Sidhu (2009) reported that the views of the Iban community were also sought when a Royal Commission set up by Sultan Omar Ali Saifuddin III on the possibilities of Brunei joining Malaysia in 1961 and Orang Kaya Gimang Anak Perait, an Iban community leader from Temburong was part of the Royal Commission. Orang Kaya Setia Laila Kana Anak Mudin, the first Penghulu of Mukim Melilas was recognized as the grassroots representative of all Ibans in Southern Belait (Wong, 2017) and his successor and nephew, is the current Acting Penghulu and current head of Melilas longhouse, Pehin Dato Pekerma Dewa Hj Mohammad Ali Abdullah Itam. It was an honour for the Iban community when Pehin Dato was elevated as a life peer, signifying his contribution to the state. In 2016, the Sultan personally financed B $\$ 2$ million to build a 


\section{Li Li Pang}

new concrete longhouse with 14 rooms to residents of Mukim Melilas when he heard of the difficulties of the residents living in the remote area. It is also important for the state to have a presence in the remote area as encroachment from the neighboring country (The Brunei Times, 2011, February 12th; Brudirect, 2016, August 15th; Borneo Bulletin, 2017, April 15th; Faisal, 2018) has occurred and it is in the country's best interest to provide better security presence at the national border.

As access to the rural area is difficult and the younger generation is more used to urban comfort, it is doubtful that the rural areas in Belait will ever attract people to live in the area. Hence the government has to propose new policies to encourage the settlement of people in the area. One of the important messages from the Tuais during the interviews was to seek the government's investment in hill paddy plantation. The Ibans traditionally have grown hill paddy before and would like the government to support this venture. If there is more support for agricultural activities in the area, it could perhaps encourage the younger generation to stay in the longhouses where more viable social and economic services can be created and provided. More research is needed to see the feasibility of the investment although the government of Brunei, His Majesty, in particular, has spoken on the importance of being self-sufficient in rice production, more recently at the opening of the 14th Legislative Council in March 2018 (Hazair, 2018).

During the research, it was also found that an ethnic Chinese Muslim has been appointed as KK before and currently, the current Acting Head of Bukit Sawat village in the Belait District is an ethnic Chinese Muslim. Further scrutiny on the scheme of service for Penghulu and KK of 2015 shows that ethnic origin composition is not important, though being a Muslim is an important criterion in those two positions. The Scoop, an independent local online news portal wrongly reported that candidates must be from one of the seven indigenous groups of Brunei at the time of nomination to be the new Penghulus or KKs (The Scoop, 2018, September 25th; September 27th). It is clear that non-Malays are also allowed to be village heads and Penghulus, as seen currently in Temburong and Belait Districts where Ibans have become KKs as well as Acting Penghulu. The criteria were also clearly listed in the government newspaper, Pelita Brunei when applications were open (Pelita Brunei, 2018, October 8th; October 15th).

Despite being given similar benefits as citizens of the country, however, in the country's census, there is still confusion and limited data on the 'other indigenous' people of Brunei. The national census does not list the number of other indigenous people in the country. The data provided by JPKE did not indicate the number of indigenous people who are citizens or permanent residents. As per the First Schedule of the Nationality Act, there are 15 ethnic groups who are considered to be indigenous to Brunei but in the published population census, their exact numbers are not given.

Even after the publication of the Nationality Act in 1962, there was still confusion in terms of how to group the different ethnic groups in Brunei. It was reported in old statistical yearbook of 1984/1985, that "in 1960, many of the 'Other Indigenous' population were suspected to have been included in the 'Malays' (Economic Planning Unit (EPU), 1985:8); in the 1971 census, the definition of Malays included Malays, Dusuns, Muruts, Kedayans, and Bisaya, who were previously they are included in the 'other indigenous category (EPU, 1985). It was only in the 1981 census that, Malays, Dusuns and Muruts were categorized as Malays (EPU, 1985). This explains the sudden haphazard data on the population of 'other indigenous' in Brunei (Table 1) since 1971, which saw a sudden increase of $77 \%$ from 1971 to 1981, and a sudden drop by 25\% in the 2001 data. The categorization exercise is important to ensure more reliable data can be compiled but at the same time, the method of categorization needs to be scrutinized. By the 2001 census, 'other indigenous' population have been included into "others" (JPKE, 2016:11) and this 'demotion' of the indigenous citizens of the country into the 'others' category which can include non-citizens such as Indians, did not reflect the special position of the local indigenous community of the country. 


\section{Li Li Pang}

Although it was downplayed during the interviews with the Tuais, the Iban traditional lifestyles seem to be under threat as there are fewer people living in longhouses (from observation) and as more residents embraced different religions. For example, it was reported that from 2012 to 2017, over 800 Ibans have embraced Islam, the largest 'other indigenous' non-Muslim population after the Dusuns to do so in the country (Azaraimy, 2018; JPKE, 2017). As urban-rural migration became a norm coupled with fewer incentives to stay in the rural remote area, traditional lifestyles of living off the forest and using forest resources would disappear eventually. The impact of such disappearance is not significant now, however literature on traditional knowledge is gaining traction especially in the field of medicine (Caniago and Siebert, 1998; Ahmad and Ismail, 2003; Budiman, et. al. 2018) where traditional knowledge on forest produce has potential to cure 'modern' illness, such as cancers or heart diseases.

The traditional position of a Tuai is also under threat due to dwindling number of residents in the longhouses. The government is unable to appoint a Tuai if there are not many residents living in the longhouse. Even if there is, interviews with the Tuais have indicated that the position is not popular with their family or relatives as they do not want the responsibility of being a Tuai and be living in the remote area. Finding a successor is difficult not only amongst the Tuais but also among the KKs and Penghulu, hence the government sudden change of policy to reduce the age of KKs and Penghulus to 30 years old in 2018 (Azahari, 2018) to attract younger candidates to apply for the position.

While the Tuais have informed their respective village heads as well as the District Office of the services required by the residents to make it is easier for them live in their longhouses, those services such as water, electricity and telecommunication are being provided, though at a slower pace compared to those in the urban areas. Nevertheless, those services have improved gradually and once the remote longhouses are connected, the next challenge is to create a viable industry which allows the residents, both the young and elderly to stay in the longhouses.

\section{RECOMMENDATIONS FOR FURTHER RESEARCH}

Ibans are part of Brunei's indigenous population, therefore, as with the other indigenous groups more research on the different communities should be encouraged, to understand the different culture and customs that exist in the country. Other indigenous ethnic communities in Brunei, not only the Ibans, are seeing the revival of their own identity and culture, prominently the Dusuns and recently the Kedayans (Lim, 2018) and even within these two ethnic groups, the community leadership structures are yet to be explored.

This research only focused on the government recognised and salaried Tuais of Brunei, however, the ethnic Ibans who were made KKs in the Temburong District were not interviewed or included. More research can be made to find out if the challenges faced by the KKs, are similar or different compared to those in the Belait district.

There is a need to find out how much investment is required to make hill paddy plantation a viable venture for the government to fund as requested by the Tuais. In general, the government of Brunei supports self-sufficiency in rice production, and a 'paddy culture' generation has been called for in the recent Legislative Council meeting (Norjidi, 2018) to boost interest in agricultural activities in the country. While research and investment have been made on high-yielding rice variety for the lowland rice plantations by the government (Idris, 2018), there is no mention of investment and research in hill paddy plantation yet.

Although Brunei has excellent ties with neighboring Sarawak, however forest encroachment still persists due to valuable forest products available in the Brunei forest, namely, the gaharu tree, one of the world's most expensive trees. The country has to be constantly vigilant, more so when the Sarawak government has approved plans to build a highway to bypass Brunei and the prospect of the 


\section{Li Li Pang}

highway development near the Brunei border is high (The Borneo Post, 2018, September 14th; The Star, 2018, September 7th). Not only delicate forest ecosystem near the border can be damaged however, further forest encroachment is possible due to both countries' porous borders.

\section{CONCLUSION}

The government of Brunei recognizes the Iban community and understand their significance to the country. Their traditions and customs are respected and their longhouse leadership maintained. The Ibans citizens and permanent residents are given the same benefits as with the rest of the people in Brunei and although rural facilities have improved, more can be done. The traditional positions of Tuais are under threat as rural-urban migration has reduced the number of people in living in the rural areas and the tasks of the Tuais can be now be taken over by the KKs. There is a need for the government to play an active role to ensure the rural areas of Brunei receive minimum investment and development, to ensure the continued presence of rural communities in remote areas. Not only do their presence help with national border security, the institutions of Tuais can also continue, preserving the leadership structure and culture of a minority indigenous population of Brunei.

\section{REFERENCES}

Ahmad, F.B. and Ismail, G. (2003). Medicinal Plants Used by Kadazandusun Communities Around Crocker Range. ASEAN Review of Biodiversity and Environmental Conservation (ARBEC), Vol. 1, pp. 1-10.

Azahari, I. (2018, September $\left.16^{\text {th }}\right)$. Age Limit Lowered for Village Heads, Penghulus. Borneo Bulletin, Retrieved https://borneobulletin.com.bn/age-limit-lowered-for-village-headspenghulus/

Azaraimy, H.H. (2018, May 29 $\left.9^{\text {th }}\right) .450$ Embrace Islam Annually in Brunei. Borneo Bulletin, retrieved https://borneobulletin.com.bn/450-embrace-islam-annually-in-brunei/

Borneo Bulletin, (2017, April 15 $\left.5^{\text {th }}\right)$. Brunei Fighting Tooth and Nail to Protect Forest. Retrieved https://borneobulletin.com.bn/brunei-fighting-tooth-nail-protect-forest/

Brown, D. E (1970). Brunei: The Structure and History of A Bornean Malay Sultanate. Monograph of the Brunei Museum Journal, Vol 2, No. 2. Brunei: Muzium Brunei.

Brudirect (August $15^{\text {th }}$ 2016). Sultanate to Use Technology to Manage Forest Resources, Curb Illegal Logging. Retrieved http://brudirect.com/news.php?id=11586

Budiman, Ed, Hairah, U., Haeruddin, Tejawati, A, Darmawan, S. and Wahyuni. S. (2018). Biodiversity Information System of Medicinal Plants from Tropical Rainforest Borneo Based on Traditional Knowledge Ethic of Dayak. Advance Science Letters, Vol. 24, (11), pp. 86688673.

Caniago, I. and Siebert, S.F. (1998). Medicinal Pant Ecology, Knowledge and Conversation in Kalimantan, Indonesia. Economic Botany, Vol. 52, (3), pp. 229-250.

Chevallier, H. (1910). Report on the State of Brunei for the Year 1910. Singapore: Government Printing Office.

Coluzzi, P. (2010). Endangered Languages in Borneo: A Survey Among Iban and Murut (Lun Bawang) in Temburong, Brunei. Oceanic Linguistics, Vol. 49 (1), pp.119-143

De Vienne, M.S. (2015). Brunei: From the Age of Commerce to the $21^{\text {st }}$ Century. Singapore: NUS Press.

Economic Planning Unit (EPU) (1985). Brunei Darussalam Statistical Yearbook 1984/1985. Bandar Seri Begawan, Brunei: Ministry of Finance

Faisal, F. (2018, May 17 $7^{\text {th }}$. Man Jailed for Possession of Forest Produce, Illegal Entry. Borneo Bulletin.

Halperin, S. and Heath, O. (2017). Political Research: Methods and Practical Skills: $2^{\text {nd }}$ Edition. NY, USA: Oxford University Press.

Hazair, H. (2018). Sultan Urges Parliament to Find More Avenues of Economic Growth. The Scoop, March 5 5 ${ }^{\text {th, 2018. Retrieved https://thescoop.co/2018/03/05/sultan-urges-parliament-find- }}$ avenues-economic-growth/ 
Idris, A. (2018, March $7^{\text {th }}$. MPRT Targets 4-Fold Rise in Paddy Production. Borneo Bulletin. Retrieved https://borneobulletin.com.bn/mprt-targets-4-fold-rise-in-paddy-production/

Jabatan Perancangan dan Kemajuan Ekonomi (JPKE)(2018). Population Census 2001 and 2011. Personal Communication.

Jabatan Perancangan dan Kemajuan Ekonomi (JPKE)(2017). Highlights 2017. Accessed http://www.depd.gov.bn/SitePages/Population.aspx

Jabatan Perancangan dan Kemajuan Ekonomi (JPKE)(2016). Brunei Darussalam Statistical Yearbook 2016. Brunei Darussalam: Prime Minister's Office.

Lim, D. (2018, July 31 ${ }^{\text {st }}$ ). Spotlight on Kedayan Way of Life. Borneo Bulletin. Retrieved https://borneobulletin.com.bn/spotlight-on-kedayan-way-of-life/

Ministry of Home Affairs (MOHA) (1992a). Skim Perkhidmatan Penghulu Dan Ketua Kampong Negara Brunei Darussalam. Bandar Seri Begawan: Ministry of Home Affairs.

Ministry of Home Affairs (MOHA), (1992b). Skim Perkhidmatan Ketua Rumah Panjang Negara Brunei Darussalam 1992. Bandar Seri Begawan: Ministry of Home Affairs

Ministry of Home Affairs (MOHA) (2015). Skim Perkhidmatan Penghulu Dan Ketua Kampong Negara Brunei Darussalam 2015. Bandar Seri Begawan: Ministry of Home Affairs.

Norjidi, D. (2018, March 21 ${ }^{\mathrm{st}}$ ). 'Paddy Culture' Needs to be Continued From Generation to Generation. Borneo Bulletin. Retrieved https://borneobulletin.com.bn/paddy-culture-needsto-be-continued-from-generation-to-generation/

Pang, L.L. (2015). Minority Participation in an Islamic Negara. Journal of Islamic Governance, Vol, $1(1)$.

Pang, L.L. (2018). Penghulu and Ketua Kampongs: Relevancy and Challenges in Brunei Darussalam. Advances in Social Sciences, Education and Humanities Research, Vol. 191, pp. 173-187.

Pelita Brunei (2018, October $8^{\text {th }}$ ). Iklan Jawatan Kosong Dalam Kementerian hal Ehwal Dalam Negeri.

Retrieved http://www.pelitabrunei.gov.bn/Lists/IklanIklan/NewDisplayForm.aspx?ID=2259\&ContentT ypeId=0x01000F874A50B2D9A0468BBD282478C3037F

Pelita Brunei $\left(2018\right.$, October $\left.15^{\text {th }}\right)$. Iklan Jawatan Kosong Dalam Kementerian hal Ehwal Dalam Negeri.

Retrieved http://www.pelitabrunei.gov.bn/Lists/IklanIklan/NewDisplayForm.aspx?ID=2284\&ContentT ypeId=0x01000F874A50B2D9A0468BBD282478C3037F

Sercombe, P. (1999). Adjacent Cross-Border Iban Communities: A Comparison with Reference to Language. Bijdragen tot de Taal-, Land- en Volkenkunde / Journal of the Humanities and Social Sciences of Southeast Asia and Oceania, Vol 155 (4), pp. 596-616

Sidhu, J.S. (2010). Historical Dictionary of Brunei Darussalam. Maryland, USA: Rowman and Littlefield.

Temburong District Website (2018). Profile Mukim. Retrieved http://temburong.gov.bn/SitePages/Profil\%20Mukim.aspx

The Borneo Post $\left(2013\right.$, October $\left.15^{\text {th }}\right)$. Don't Involve in Rural-Urban Migration Aimlessly, Ibans Told. Retrieved http://www.theborneopost.com/2013/10/15/dont-involve-in-rural-urbanmigration-aimlessly-ibans-told/

The Borneo Post (2016, July $\left.3^{\text {rd }}\right)$. Miri in Need of More Iban Community Leaders. Retrieved http://www.theborneopost.com/2016/07/03/miri-in-need-of-more-iban-community-leaders/

The Borneo Post (2018, September $\left.14^{\text {th }}\right)$. Rethink Decision for Pan Borneo Highway to Bypass Brunei - MP. Retrieved http://www.theborneopost.com/2018/09/14/rethink-decision-for-pan-borneohighway-to-bypass-brunei-mp/

The Brunei Times (2011, February 12th). Organised Crime Hurting Brunei Forests. The Brunei Times. Retrieved https://www.illegal-logging.info/content/organised-crime-hurting-bruneiforests

The Scoop (2018, September $\left.25^{\text {th }}\right)$. Home Affairs Minister Urges Citizens to Participate in Village Elections: Voter Turnout Should Be No Less Than a Third of Registered Voters, According to Regulations. Retrieved https://thescoop.co/2018/09/25/home-affairs-minister-urges-citizensto-participate-in-village-elections/ 


\section{Li Li Pang}

The Scoop (2018, September $\left.27^{\text {th }}\right)$. So You Want to be A Ketua Kampung? Here 's the Full List of Vacancies. Retrieved https://thescoop.co/2018/09/27/so-you-want-to-be-a-ketua-kampungheres-the-full-list-of-vacancies/

The Star $\left(2018\right.$, September $\left.7^{\text {th }}\right)$. Realignment to Bypass Brunei. The Star. Retrieved https://www.thestar.com.my/metro/metro-news/2018/09/07/realignment-to-bypass-bruneibaru-diversion-of-pan-borneo-highway-will-bring-tremendous-benefits-to/

Wasil, W. (2018, September 27 $7^{\text {th }}$. So You Want to be A Ketua Kampong? Here's The Full List of Vacancies. Retrieved https://thescoop.co/2018/09/27/so-you-want-to-be-a-ketua-kampungheres-the-full-list-of-vacancies/

Wong, A. (2017). The Story Behind the Revival of Brunei's Most Remote Settlement. Retrieved https://www.bizbrunei.com/2017/10/story-behind-revival-bruneis-remote-settlement-melilas/ 
JOURNAL OF BORNEO-KALIMANTAN. VOL 4(2) 2018

\section{APPENDIX 1}

22 CAP. 15

Brunei Nationality

\section{FIRST SCHEDULE}

(section 4)

MEMBERS OF GROUPS OF PEOPLE WHO ARE CONSIDERED TO BE

INDIGENOUS TO BRUNEI DARUSSALAM WITHIN THE MEANING OF

THIS ACT

Bukitans

Dayaks (sea)

Dayaks (land)

Kalabits

Kayans

Kenyahs (including Sabups and Sipengs)

Kajangs (including Sekapans, Kejamans, Lahanans, Punans, Tanjongs and Kanowits)

Lugats

Lisums

Melanaus

Penans

Sians

Tagals

Tabuns

Ukits

and any admixture of the above with each other, or with a subject under section $4(1)(a)$. 